\title{
Guidelines for effective community transformation from a practical theological perspective: An African case study
}

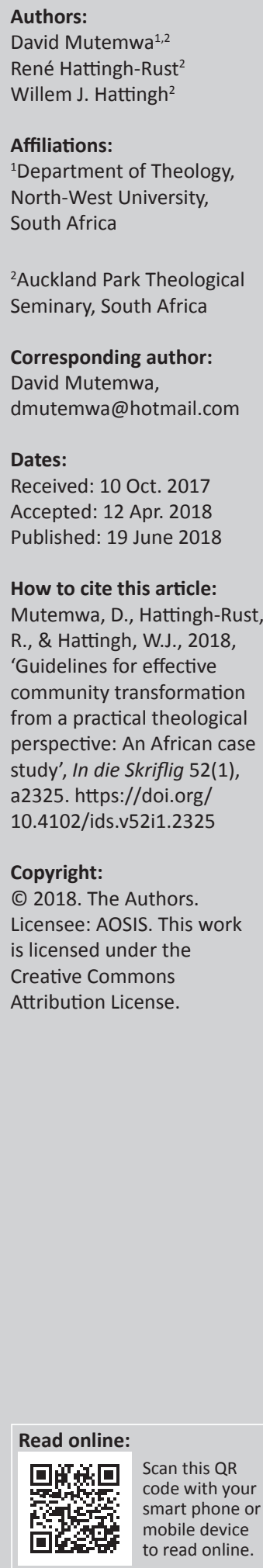

This article reports on the pragmatic task that formed the conclusion and flagship part of a master's degree (MTh) research study into the effectiveness of the transformational task of the church in the Sesheke area. The methodological approach in the research has been according to Osmer's four tasks of practical theological interpretation, namely the descriptive-empirical, interpretive, normative, and pragmatic tasks. Each of these tasks has been used to address a specific stage of the study. A separate preceding article by the same authors focused on the first task, while this article addresses the fourth. The Pastors' Fellowship, referred to as the Sesheke Church in this article, has accepted their biblical mandate to engage in community transformation activities aimed at alleviating the plight of the poor and less-privileged people in society. The overall outcome of the research has shown that the Sesheke Church has failed at its transformational task for several reasons, as will be briefly discussed in this article. Therefore, the pragmatic task has endeavoured to formulate practical guidelines to enhance the effectiveness of the Sesheke Church's task. The authors believe that this article will contribute to the discourse of practical theology regarding community transformation from the unique context of the Sesheke Church's transformational task and the respective guidelines for effective community transformation. Burns and Grove state that understanding the meaning of a phenomenon in its context makes it easier to understand similar phenomena in other contexts.

\section{Introduction}

This article reports on the pragmatic task that formed the conclusion and flagship section of a master's degree (MTh) research study conducted on the effectiveness of the Sesheke Church's transformational task. Osmer's (2008) four tasks of practical theological interpretation have been employed in the original research, namely the descriptive-empirical, interpretive, normative, and pragmatic tasks. According to the findings of the descriptive-empirical task, the Sesheke Church has not been effective at its transformational task for several reasons, as outlined later under the 'Findings of the descriptive-empirical task' section of this article. The pragmatic task has therefore endeavoured to develop practical guidelines that could be employed to enhance the effectiveness of the church's task to transform their local community. The guidelines result from a synthesis of all the three preceding tasks in the bigger research. As such, this article provides practical guidelines for effective community transformation from a practical theological perspective of the Sesheke Church's transformational task as an African case study. ${ }^{1}$

\section{Background and statement of the problem}

Sesheke is a small semi-rural town in Zambia's Western Province and is situated right at the border of Zambia and Namibia. The town has a cross-section of people, including those from Angola, giving it a unique blend of lifestyle and challenges of its own. Another unique aspect about the Sesheke community is its history and relationship with the Zambezi Sawmill that was liquidated in 1999. The Sawmill provided job opportunities for the local community, and also caused an influx of people from other communities. Its abrupt closure, however, has been a severe blow to an already vulnerable community. Even worse is the fact that the company closed without paying workers their dues, causing great suffering to workers and their families who live from hand to mouth.

The town of Sesheke has the country's highest timber revenue collection from 17 out of 46 national forest reserves in Western Zambia, but still remains among the poorest and least-populated towns 1.A case study focuses on a single case or limited number of cases, studied in depth over a specific period of time (O. 
in the country (Vinya et al. 2012:4). It is in response to such a situation that the Pastors' Fellowship of Sesheke formed a new sub-committee that would engage the church, government, and all other stakeholders in a process of transformation for local communities to benefit from their God-given resources.

The problem that has prompted the researcher to undertake the research is that the Sesheke community has not transformed, despite the abundance of natural resources and transformational efforts by the Sesheke Church since 2007. This can be appropriately linked to Korter's (1991:1-20) observation after studying more than 100 organisations that intentionally initiated processes of transformation, namely that most transformation efforts fail due to two lessons that he drew from his study. Firstly, transformation involves deep change (Quinn 1996) and it passes through a series of phases that require considerable time and effort. Skipping steps to speed up the process usually does not pay off in the long run. Secondly, critical errors in any of the steps can have devastating impact on the entire process.

The researcher served as chairperson of the Sesheke Church's transformational task committee for seven years from its inception and has, therefore, been motivated to conduct a systematic inquiry into the effectiveness of the Sesheke Church's transformational task.

The concept of church in this article refers to the body of believers in Jesus Christ that transcends denominational boundaries. More specific, it refers to a group of church leaders, namely the Pastors' Fellowship of Sesheke, which was formed within the broader church with the specific obligation of improving the welfare of the Sesheke community. It has been accepted for the purpose of this study, that the church has a significant role to play in transforming the whole person.

\section{Central research question}

In view of the foregoing background and statement of the problem, the central research question is: How effective is the Sesheke Church in its transformational task to bring about economic and social transformation within their local community?

\section{Aim of the study}

The aim of the study has been to determine the effectiveness of the Sesheke Church's transformational task in bringing about economic and social transformation within their local community. The Sesheke Church's task in essence entails a total transformation and holistic approach to all other relevant contextual issues such as poverty alleviation, lifestyle, religious ethics, justice, and politics. Therefore, this article will also contribute to the understanding of practical theology, especially with regard to practical theological perspectives on community transformation from the unique context and situation of the Sesheke Church's transformational task.

Accordingly, the four objectives of the study are as follows:

- To understand the current church praxis in the Sesheke area with special regard to transformation, resulting from a descriptive-empirical investigation.

- To determine the contribution of existing research to the understanding of the transformational task of the church.

- To understand from Scripture principles that can be normative guidelines to the transformational task of the local church.

- To develop specific guidelines through critical reflection of the pragmatic task to be employed in the transformational task of the church in the Sesheke area.

This article focuses on the fourth objective and the pragmatic task in accordance with Osmer's (2008) research model.

\section{Central theoretical argument}

The central theoretical argument is that when the Sesheke Church perform an effective transformational task that consists of a good understanding of the target community and principles of community transformation, they would be instrumental in bringing about economic and social transformation within their community, because they would have engaged in a responsible and organised process that empowers the community to be self-reliant.

\section{Research methodology}

The research has followed the elements of research design according to Osmer (2008:48), namely purpose of the research, strategy of inquiry, research plan (methods) and reflexivity (reflection on the meta-theoretical assumptions informing the study). Apart from being one of the most widely-used methodologies currently used for doing research in practical theology (Woodbridge 2014:2), the researcher has employed Osmer's (2008) model because it also deals with the practical theological interpretation of the research question (Osmer 2008:4). This is accomplished through its combination of the descriptive-empirical, interpretive, normative, and pragmatic tasks.

The focus of this article is on the pragmatic task, which involves forming and enacting strategies of action that influence events in ways that are desirable (Osmer 2008:176). This task is grounded in a spirituality of servant leadership by reflecting on Jesus Christ as the embodiment of God's royal rule in the form of a servant (Osmer 2008:183-184). Accordingly, this task also involves reflecting on several key issues such as the mission of the community of disciples, leading change, and adjustments that need to be made for change to occur. In the light of the foregoing trends, this article focuses on the pragmatic task of formulating guidelines for effective community transformation from a practical theological perspective, by reflecting on Jesus Christ and the task of the church in Sesheke. The church is 
hereby seen as a catalyst for the desired transformation according to Osmer (2008:191).

As the guidelines result from a synthesis of the preceding three tasks, it is imperative to provide in summative form the perspectives from the preceding tasks before attending to the guidelines.

\section{Perspectives from preceding research tasks}

Perspectives from the three preceding research tasks are hereby given in brief, followed by a detailed discussion of the specific guidelines for effective community transformation in Sesheke, in order to develop a concrete and coherent argument.

\section{Findings of the descriptive-empirical task}

An irrefutable outcome of the descriptive-empirical research is that the Sesheke Church has failed at its transformational task - participants in the interviews have given several reasons for the failure. These include a lack of participatory transformational practices, church politics and interests for personal gain, an oversimplified approach to transformation, and an underlying dualistic view of the task of the church that favours spiritual guidance as opposed to physical well-being. A lack of skills and understanding of the transformational task, non-sustainable interventions by the church, and a lack of resources have equally been identified as reasons for the failure of the Sesheke Church's transformational task. The participants did identify interventions of the church that are beneficial to the community, but such interventions could not be described as sufficient to bring about community transformation. The expectations of the participants regarding the transformational task of the church are that the church should transform the community holistically, liaise with the government on behalf of the people, and empower the people. They, however, acknowledge that the transformational task of the Sesheke Church has been hampered by several challenges - some related to specific community characteristics and other to general operational practices.

\section{Interpretive perspectives}

The contributions of the interpretive research in a larger framework have revealed, among others, that community transformation is about meeting the affected people's concrete felt needs, and therefore the local people should participate fully in their transformation process. It is a process that requires deep change and the impetus for the change must predominantly come from within the local community itself (Collier 2007:9, 71). External experts and organisations should play a minimal facilitating role without dictating the course of action.

The key to transformation of the poorest communities is economic growth and the key to economic growth is investment (Collier 2007:44). Barriers to transformation and economic growth in Zambia, and subsequently in Sesheke, are the natural resource curse or Dutch disease, ${ }^{2}$ being landlocked, and bad governance (Collier 2007:38, 53, 64).

Participation is central to all other relevant alternative approaches to community transformation (Dodge \& Bennette 2011; Kretzmann \& McKnight 1993).

As part of the solution, external aid should supplement local efforts, but it must be handled in such a way that it does not disempower the local people and cause dependency (Blackman 2007:30; Collier 2007:100-123). Development aid is in this case preferred to direct support for consumption according to the latter of the two just-cited authors.

\section{Normative perspectives}

The normative task has been considered in its three basic dimensions, namely theological interpretation, good practice, and ethical reflection (Osmer 2008:161). Under theological interpretation, the exegeses of the two texts of Scripture guiding this research (Mt 5:13-16 and Mt 25:35-40) has shown that the church has the mandate to engage in community transformation activities that seek to alleviate the plight of the poor and needy with the overall aim of glorifying God. It is also very important for the Sesheke Church to acknowledge the Word of God and working of the Holy Spirit as integral factors of community transformation.

The concept transformational task is hereby used and applied within the context of practical theological reflection. As such, the multidimensional nature of practical theology functions as a framework that provides sufficient breadth to engage relevant interdisciplinary discourses, while allowing for thick descriptions of transformation in different contexts, and thereby providing sufficient depth also to allow for the rich texture and contextual understanding of the Sesheke Church's transformational task (Dreyer 2008:10).

Ethical reflection has shown that there is an ethic of equalregard grounded in the narratives of creation and the ministry of Jesus Christ that points to the inherent dignity and worth of all humans. This is an important premise in many respects, as ethical propagation of the gospel must address both the spiritual and physical dimensions of persons and communities, which are affected in one way or another by the prevailing social, economic, environmental, and political conditions. Therefore, it is correct for the church in Sesheke to engage in a community transformation task, but it should ensure to establish a relevant biblical and moral basis to be effective.

\section{Guidelines for effective community transformation}

The guidelines for effective community transformation, resulting from a synthesis of the three preceding tasks in the

2 Dutch disease (or the natural resource curse) is a term derived from the effects of the North Sea (or the natural resource curse) is a term the 1960 s and it is now used the North Sea gas discovery on the Dutch economy in the 1960s and it is now used as an economic concept to explain the negative consequences caused by an unnatural focus on a specific natural resource sector, to the detriment of all other sectors (Collier 2007:39-40). 
original research, will now be presented. The results have been divided into four themes with respective subthemes. The themes and subthemes have become the specific practical guidelines aimed at enhancing the effectiveness of Sesheke Church's transformational task as discussed hereafter. The main themes are hereunder listed and then a detailed discussion of each theme and their respective subthemes follows.

- Understand community transformation.

- Identify local barriers to transformation and possible remedies.

- Identify areas of influence.

- Utilise local resources.

\section{Understand community transformation}

One of the main reasons the Sesheke Church has failed at its transformational task is lack of skills and understanding of the transformational task, as revealed by the descriptiveempirical task. The interpretive task has shown that the meaning of a transformational task is tied to the concrete felt needs of the specific community (Swanepoel \& De Beer 2015:47).

For the people of Sesheke, transformation involves, among others, alleviating the plight of the poor and less privileged in society. This is in accordance with the biblical instruction for Christians to respond to all human needs, especially those of the poor and less privileged (Adeyemo 2006:1164).

The church in Sesheke must understand the following principles of community transformation in order to be more effective in performing their transformational task.

\section{Ensure full community participation throughout}

Participation is the central concept and foundational principle of community transformation (Tesoriero 2010:144). As Dahama and Bhatnagar (1985) write:

[...] before action can take place, it must be approved or legitimated by those holding such power in the village, or the group, or the local system, whatever we may call it. (p. 223)

To bypass such leaders may cause opposition and may result in the failure of the programme.

\section{Emphasise change from within}

A key feature of community transformation is action at grassroots level, where the affected people themselves take the leading role, with external experts and organisations playing a minimal facilitating role (Swanepoel \& De Beer 2015:44). 'Change in the societies at the very bottom must come predominantly from within' (Collier 2007:9, 71).

\section{Identify concrete community felt needs}

Needs identification is a prerequisite for action and local people must be involved in identifying their own needs (Adejunmobi 1990:226; Jeppe 1985:28). These must be concrete felt needs by the local people themselves, not only needs identified by an external specialist or consultant. This might be one of the biggest mistakes the Seshske Church has made in its previous transformational efforts.

The perceived need of the external organisation has been forest preservation, but it is evident from the interviews that the real need of the people is survival. The prevalent state of poverty in which the people of Sesheke find themselves has been a strong determinant of other human and environmental problems being experienced in the area (Swanepoel \& De Beer 2015:111). According to the biblical injunction, the church will tarnish its God-given light and salt resemblance when it does not address the true need of the people of Sesheke.

\section{Employ a holistic and integrated approach}

As seen from the empirical research, the transformational efforts of the church have been perceived to be oversimplified and inadequate, as they have not provided a holistic solution to the needs of the community.

The interpretive task has revealed that the most fundamental characteristic of community transformation is that it follows an integrated approach to the problems of poverty and transformation in attempting to eradicate poverty (Mohaneng 2000:127). The normative task has also shown that economic, social, and environmental transformation should follow salvation of the soul (Myers 1999:3). In short, effective transformation should be an integrated holistic approach.

\section{Empower local communities}

One of the expectations of the participants regarding the church's transformational task is that the church should have empowered the local people to determine their own transformational course. According to the interpretive task, the local people themselves should assume full responsibility and participation from the outset if the transformational projects are to succeed (Dodge \& Bennette 2011:5; Gabriel 1991:1-7; Myers 1999:147-149; Swanepoel \& De Beer 2015:44). Although empowerment is complex and defined differently by different authors (Lord \& Hotchison 1993:5; Wallerstein 1992; Whitmore 1988:13), Whitmore (1988) states that there are some common underlying assumptions for transformation as hereunder bullet:

- Individuals are assumed to understand their own needs better than anyone else, and therefore should have the power both to define and to act upon them.

- All people possess strengths upon which they can build.

- Empowerment is a lifelong endeavour.

- Personal knowledge and experience are valid and useful in coping effectively.

Without empowerment transformation cannot be sustained.

\section{Ensure sustainability of transformational projects}

All the foregoing subthemes, in one way or another, contribute to sustainability of the transformational task. 
The Sesheke Church has, however, been found lacking in these aspects according to the preceding tasks in the original research. Sustainability refers to medium- to long-term viability and longevity of changes brought about by the transformational task (Abiche 2004:27). Therefore, it is imperative for the Sesheke Church to employ sustainable interventions such as the efficient use of available resources for the transformational task to be effective (Lopez-Ridaura et al. 2005:73).

\section{Effective planning and implementation}

The need for effective planning and implementation has been seen from the outset in the descriptive-empirical task as communities returned to their deforestation practices once the Pastors' Fellowship team left the area, because their real need for survival was not taken care of.

According to the interpretive task, effective planning should ensure that all stakeholders are involved in the planning and that the people directly affected by the plan and those who will implement it also participate in its formulation (Gabriel 1991:7). Swanepoel and De Beer (2015:204-206) state that implementation should take place according to plan because it is a plan that must be implemented.

The following is a practical example of a helpful checklist to ensure effective planning and implementation as directly quoted from the just cited co-authors:

- Does the plan address the actual issues?

- Have tasks been identified and written down?

- Is there somebody responsible for each task?

- Do the people understand the finer details of the plan?

- Is the implementation done step by step?

- Have all tasks been completed?

\section{Community research}

The empirical research has shown that the Sesheke Church moved into the community with a transformational agenda without first understanding the community through a community research. According to contributions from all three previous tasks of the original research, it is important to understand the community through a community research before moving in with a transformational agenda.

Local communities are more effective in defining and meeting their own needs (Gabriel 1991:4). In Matthew 25:35-40, one of the two pericopes that has guided the original study, the righteous are rewarded for meeting the people's own identified concrete felt needs.

\section{Ethical implications}

Throughout the transformational projects the Sesheke Church should test their transformational practices and norms against biblical and universally accepted ethical principles. The first is that environmental protection should not be done at the expense of human survival. Concern for the poor and needy, especially those considered to be least important in society, should be the top priority of the church's transformational task according to Matthew 25:35-40. Secondly, the use of natural resources must not reduce the resources available for present and future generations, or cause pollution and disruption. Thirdly, general principles and concrete guidelines such as equal-regard should orient the church about moral issues at stake in the discourse of their transformational task.

\section{Identify local barriers to transformation and possible remedies}

The interpretive task has shown that the transformation of each community should also deal with specific local factors that have an influence on the desired transformation, either positively or negatively. According to Milojevic (2012:1), these include natural characteristics, internal structures, local history and tradition, some social-cultural or socialeconomic background, political manifestations, as well as religious background and influence. It would therefore be prudent for the Sesheke Church to address and strategically incorporate these factors in their transformational projects. The descriptive-empirical research has revealed some of the local barriers to transformation in Sesheke as outlined hereafter.

\section{A larger part of the population appears to be without the necessary education}

A major vulnerability of the community has been identified as the lack of skills, knowledge and training of the community members.

The need for an educated population has been further strengthened by contributions from the interpretive research. Firstly, the educational structure of a population is related to the economic activity and superstructure of a community. Secondly, economic reform and implementation of a transformation agenda require technical know-how and support, or a higher proportion of people with the prerequisite knowledge such as those who have attained at least secondary education (Collier 2007:71). It is therefore important for the Sesheke Church to work at enhancing human capacities for implementation of the transformation agenda by improving the education of the local population (United Nations Economic Commission for Africa 2013:9).

\section{Cultural and language barriers}

The descriptive-empirical task has revealed that apart from the internal cultural diversities, Sesheke has also become home to people from the neighbouring country of Angola, causing cultural and language barriers to the transformation process.

One of the core principles of traditional African culture, however, is 'humanness', commonly referred to as ubuntu. It is well expressed by the Xhosa saying: Umntu ungumntu ngabanye abantu - a person is a person through other persons (De Wet 2011:28). Accordingly, identity among Africans should not be understood in relation to individuated selves 
and ownership, but through interaction with other persons who all participate in each other's identities (Akrong 1999:8). This norm and value of communal ownership is strategically linked to the importance of community ownership, which is fundamental to community transformation.

\section{Accessibility of communities}

Accessibility of communities has been made difficult not only by the lack of transport, but also the non-existence of roads to many communities. The community expects the church to resolve the problem of transport to reach the communities, but this is a project of a bigger magnitude than the church resources. It calls for external aid and government lobbying, an aspect that will be dealt with later under the section, 'The place for aid'.

\section{Natural resource curse (Dutch disease)}

The natural resource curse (Dutch disease) in Sesheke is evidenced by overdependence on timber production as a primary economic activity and export product. As a practical case study, when Zambezi Sawmills was liquidated, everything came to a standstill and the people became destitute. After that the people of Zambezi Sawmills, however, emerged as good farmers who just needed to be empowered.

Overdependence on natural resources like timber can be detrimental to community transformation in that it crowds out other viable sectors like agriculture and manufacturing, which might be the ones to bring about economic growth and transformation (Collier 2007:40-42; Maser 1997:121).

As remedial measures, the Sesheke Church and community should consider alternative livelihoods such as agriculture, export diversification, and orientation towards good neighbours like Namibia and Botswana. This aspect will be addressed in detail in the remedy to the next barrier and the specific subtheme on farming under 'Utilise local resources', respectively.

\section{Being landlocked}

Sesheke is landlocked because of being part of a landlocked country. This causes it to fall behind in overall growth and trade, as it is subjected to other problems of landlocked areas of Africa as discussed under the interpretive task in the original research. It is, however, less landlocked, so to say, than the rest of Zambia because it is located right at the border of Zambia and Namibia, a good neighbour. ${ }^{3}$ The Katima Mulilo Bridge across the Zambezi River, completed in 2004, and the paved road from Sesheke to Livingstone have made Sesheke an important transit point or link for the so-called Trans Caprivi Corridor which links the Port of Walvis Bay with Zambia, the southern part of the Democratic Republic of the Congo (DRC) and Zimbabwe (Walvis Bay Corridor Group 2016). A direct result of this development is the great increase of road freight traffic, investment, and construction boom that has been rapidly transforming both Sesheke and the neighbouring Namibian border town of Katima Mulilo. Sesheke is also connected by road to Botswana.

Sesheke's location offers opportunities in terms of crossborder trade and linkage to the sea. Instead of making Namibia and Botswana transit routes to South Africa for the bigger global markets overseas, the small community of Sesheke would do well to orient its economy towards Namibia by making it the target market for its forestry and agricultural products. Expert knowledge would be very helpful in this regard.

\section{Bad governance}

As earlier indicated, bad governance relates directly to Zambia as a country and subsequently to Sesheke as part of that country. The poor economic growth performance in the Sesheke area can also be attributed to bad governance, because there is a strong relationship between poor economic growth and bad governance as revealed by the interpretive task (Collier 2007:64-65; Khan 2006; Kraufmann \& Kraay 2003). Moreover, the physical command of natural resources by the government or hereditary elite, such as has been the case with Sesheke, is less likely to develop necessary checks and balances, and as a result economic growth and transformation are hampered (Collier 2007:40-42).

The Sesheke Church should advocate for checks and balances in the local government sector than mere the promotion of government effectiveness (Collier 2007:64-65). According to the descriptive-empirical and interpretive tasks, checks and balances should apply to the transparent use of natural resources and the respective revenues accrued from there, budget and expenditure tracking, national and local or private media coverage, social justice, and the distribution as well as separation of powers. This too, is an integral part of being salt of the earth and light of the world in accordance with the normative perspectives.

\section{Identify areas of influence}

The Sesheke Church needs to identify and incorporate key areas of influence in the community to be effective at its transformational task. Accordingly, the following four areas of influence have been identified from the preceding research tasks.

\section{Church and other faith-based on organisations}

Findings from the descriptive-empirical task have shown that the Sesheke Church already has had a group of people around them who are still willing to listen to them and trust them. This is basically proven by the wide range of expectations the people of Sesheke had regarding the church's transformational task. Therefore, it is easier for the Sesheke Church to extend its influence in the area towards the achievement of transformation goals. 
The interpretive task has shown that the churches and other religious organisations, such as faith-based organisations (FBOs), have a very strong influence on society and should, therefore, be mobilised for community transformation (Awolalu 1996:1; TerHaar \& Ellis 2006:356). For instance, research in the developing world has shown that the church has played a role in bringing about important economic and social changes (Attanasi \& Yong 2012:94; Berkley Centre for Religion, Peace, and World Affairs 2015; Mathewes s.a.).

The above trends are in line with the biblical expectation in the normative task for the church to have a positive influence as the salt of the earth and light of the world.

\section{Culture}

Culture has a strong influence and cultural diversity within communities is a force to reckon with when considering effective community transformation (Maser 1997:113). In accordance with the principle of humanness (ubuntu) as already discussed, the Sesheke Church should promote unity in diversity and use this principle as a strength for the transformational task. Based on the Word of God as revealed by the normative task, Christians should love, support, and appreciate all people regardless of their sex, race, or language. This is a strong influence that can be utilised to strengthen the church's transformational task.

\section{Politics}

In view of the preceding three tasks, politics has been categorised in three forms, namely government politics, community-based politics, and church politics. All three these forms of politics have direct influence on community transformation.

Government politics: From the descriptive-empirical task perspective, government projects are either a positive contribution, or a negative hindrance as the government has its own agenda, which may not necessarily be aligned with that of the needs of the community. It is therefore important for the church to understand and critically define the role of government when cooperating with government departments. According to the interpretive research, the highly unequal distribution of power and resources inherent in the world economic system can also lead to government officials, hereditary elites, and other development facilitators not being held responsible for effective service delivery to the target communities.

The biblical standpoint in view of the above is that the church possesses the spiritual knowledge, wisdom, and way of life required to preserve this world in a proper condition, not the religious leaders or government officials who do not acknowledge the sovereignty of God.

Community-based politics: This is a rather narrow but very important dimension of politics brought about mainly by the desperate competition for resources and the right to be heard at community level (Zuern 2011:137). Community-based politics tends to have a bearing on the overall outcome of a transformation process, either positively or negatively, as revealed by the interpretive task.

Equality should be the guiding principle regarding community-based politics in accordance with the normative task. Osmer (2008:151) writes that there is an ethic of equalregard grounded in the narratives of creation and the ministry of Christ that points to the inherent dignity and worth of all humans. If the church understands this dynamic, it can play a vital role in handling community-based politics positively and successfully.

Church politics: It has been revealed by the descriptiveempirical task that the success of the church's transformational task was also impeded by the self-centred actions of churches and leaders that were aimed at improving their own status, position or to achieve greater power. According to the interpretive task, religious identity and politics of identity have been recognised as a significant contemporary phenomenon. It comes to the fore when such identity groups seek to find ways of recognition, competing for resources, gaining public voice, arguing for their rights, and in some cases winning converts and friends (Woodhead, Kawanami \& Patridge 2009:24). If not checked, this can have an immediate devastating effect on the transformational task of the church.

Community transformation is about meeting the affected people's needs (Cernea 1991; Chambers 1983), not personal gain or glory as revealed by all three preceding tasks. Here again, equality ought to be the guiding principle in cautioning these destructive vices. This entails the equal distribution of wealth, resources, and social justice.

\section{External aid agencies or donors}

External aid agencies or donors can have either a positive or negative influence on a transformational process, depending on how the church and local community handle them. For example, one of the striking discoveries in the descriptiveempirical task is that the origin of the vision and funding for the Sesheke Church's transformational task appears to have come from an external organisation, namely the Evangelical Fellowship of Zambia (EFZ). As earlier mentioned, their perceived need of forest preservation proved to be inaccurate because the true pressing issue with the people of Sesheke is survival.

The Pastors' Fellowship, on the other hand, has shown evidence that they have been aware of the true needs of the communities, but have not been able to go against the programme of EFZ because of the funding. As a result, the transformation projects died along with the withdrawal of EFZ and their funding.

The interpretive task has revealed that it is important for organisations such as the church to have the necessary skills and understanding of working with donors from a broader 
perspective when engaging in community transformational projects. This aspect will be further discussed under the section on 'The place for aid'.

\section{Utilise local resources}

The participants in the interviews seem to think that one of the reasons the Sesheke Church has failed in its transformational task is that it has not harnessed the assets of the community. The strengths, resources, and potentials within a community can be utilised to bring about change and development. Asset-based community development is based on the belief that everyone has 'capacities, abilities and gifts and that the quality of an individual's life depends in part on the extent to which these capacities are used, abilities expressed and gifts given' (Kretzmann \& MacKnight 1993).

From the interpretive perspective, no community project can go without the identification of local assets along with concrete felt needs (Swanepoel \& De Beer 2015:44). Local assets include the talents and skills of individuals, organisational capacities, political connections, buildings, facilities, and financial resources (Page-Adams \& Sherraden 1997). As the assets are used, they also develop, especially humans, who are the most important assets (Swanepoel \& De Beer 2015:44). According to the normative task, Christians also possess spiritual knowledge, wisdom, and the way of life required to transform the community.

Each community should boast of some unique combination of assets on which to build its future. The chances of success depend on the capacities of those in the society - the local people.

\section{Community audit}

This is inextricably linked to community research but more focused on conducting a detailed inventory of community assets than the identification of needs (Kretzmann \& McKnight 1993:4). In what they refer to as capacity mapmaking, the duo write that an inventory conducted on household by household, building by building, block by block, will lead to the discovery of a vast and often surprising array of individual talents and productive skills, few of which are mobilised and utilised for community transformation. This basic and biblical truth about the giftedness of every individual and community is important to persons and communities that often find themselves marginalised and deprived like the Sesheke community.

\section{Local capacity building}

Capacity building is inseparably linked to the concept of asset-based community development (Kretzmann \& McKnight 1993). The interpretive task has shown that capacity building is central to the quest for sustainable transformation and has recently become a co-goal of technical assistance, not just a mere component or by- product of development programmes (Simpson 2002:10). According to Agenda 21 of the World Summit on Sustainable Development (cited by Simpson 2002:11), capacity building specifically encompasses a community's human, scientific, technological, organisational, institutional, and resource capabilities. Foot and Hopkins (2010:7) write that '... as well as having needs and problems, our most marginalised communities also have social, cultural and material assets ...'. Identifying and mobilising these resources can help a community to overcome its challenges, economically grow, and ultimately transform.

\section{Farming}

The participants in the research have identified farming as an asset and alternative livelihood within the Sesheke community. This view can be supported by the broader contribution of the interpretive task that agriculture is a top priority for most Africa economies (Gabriel 1991:52; Matunhu 2011:66-67). The main positive factor for farming in Sesheke is its proximity to the Zambezi River, which can be used for irrigation in case of a draught as revealed by the descriptiveempirical task.

The Sesheke community, however, seems to be in a predicament as they have been fighting for survival and yet their actions have been considered illegal because they have had to farm in a forest protected area in search of more fertile and sufficient agricultural land. As revealed by the interpretive task, the issue of woodland is very difficult to handle because increasing demand for food increases the economic incentive to cut down forests to create new fields to grow crops (Goodall 2012:27). Therefore, both the difficulty and solution lie in the trade-offs inherent in agricultural development and environmental protection. Here again the church should play an effective role in bringing all affected parties to a point of dialogue and resolve the matter in such a way that a 'win-win' solution is found.

\section{The local church}

In all the three tasks of practical theological interpretation in the original research, it has been revealed that the church is a major stakeholder in community transformation. The normative task highlights that the most effective tool we can wield in our efforts on behalf of the poor and needy is biblical truth (Allen 2004:9). Accordingly, Christians are supposed to make the earth better and more liveable by being initiators of divine guidance, influence, and wholesomeness.

\section{The working of the Holy Spirit in community transformation}

The Holy Spirit empowers Christians to be selfless and transform their community. According to American sociologist Berger (cited by Berkley Centre for Religion, Peace, and World Affairs 2015; Mathewes s.a.), some academicians noted, while objectively observing born-again, spirit-filled Christians (viz. Pentecostals), that they act selflessly and transform their world for the better - that they 
are a modernising force in society. The normative task has revealed that the empowerment of the Holy Spirit is an integral part of being salt of the earth and light of the world (Lk 24:49 and Ac 1:8). The following anecdote from Zambia itself may illustrate this fact:

Annakie Hattingh and Antoinette Erasmus used to go to Kasupe Bible College to conduct empowerment workshops for the [Apostolic Faith Mission] AFM of Zambia's woman in ministry. En route to Lusaka, Zambia (they travelled by combi) Annakie, while witnessing the poverty and needs of the people, felt that the Holy Spirit prompted her to talk to the women about starting and managing their own entrepreneurial businesses. Having little knowledge on this subject herself she tried to prepare as best as possible while they were travelling. At the workshop she talked to the women and gave them the little she knew. In her final comment however she told them that they are people who are born-again and baptised in the Holy Spirit and that they should ask the Holy Spirit to give them wisdom and guidance.

When they went back one year later there were at least twenty women who testified of how, after hearing her talk, have started a business and now a year later, they are able to support their families (some with big extended families) with their new business. Of importance is that they testified of how the Holy Spirit strengthened and motivated them and guided them in this new, unfamiliar venture they took. (From an interview conducted with A. Hattingh, Johannesburg, 21 October 2016)

The Sesheke Church would do well to understand the resources available to them through the working of the Holy Spirit in people.

\section{The place for aid}

The descriptive-empirical and interpretive tasks revealed that some of the community transformation projects might require external support because they are of bigger magnitudes than the capacities of the local church and communities (Blackman 2007:30; Collier 2007:62). Aid alone, however, is not sufficient to bring about growth and transformation, but can be part of the solution (Collier 2007:107-116; Goldthorpe 1990:279; Sachs 2015:33-34). The local church and community must therefore have necessary skills to effectively partner with Christian organisations and non-government organisations (NGOs) to source for support for bigger projects (Collier 2007:17, 42). The following five skills are helpful in this regard (Collier 2007:100-123):

- Understand the complexity of aid. If not used properly, aid can breed corruption and dependency.

- Attract aid by promoting good governance and policies. Aid tends to be more effective where governance and policies are already reasonable.

- External support should supplement local efforts and resources.

- Development aid is preferred to direct support for consumption.

- Strengthen collaboration between the community and external organisations.
The focus of aid should be on increasing self-reliance, such as through income generation initiatives (Blackman 2007:30). In this regard, the local community is expected, with the help of partners, to help individuals and communities attain sustainable transformational development through technical, physical, and financial support to enhance bigger and longterm transformational projects (Van Hoek \& Yardley 2009:6).

The bigger transformational projects that require external support as identified from the preceding tasks of original research are the following: education across all sectors of the community; access to health services for all communities; and transport and communication.

\section{Discussion and conclusion}

A critical reflection of the pragmatic task has led to the formulation of specific guidelines for effectiveness community transformation presented in this article. The guidelines result from a synthesis of the preceding descriptive-empirical, interpretive, and normative tasks in the original research.

Among others, it is important to highlight that community transformation is about meeting the affected people's concrete felt needs, and therefore the local people should fully participate in their transformation process. Change at the very bottom must come predominantly from within. Of great significance still is the realisation that the most effective tools we can wield in our efforts on behalf of the poor and needy are biblical truth and the working of the Holy Spirit.

This study has set out to make a positive contribution to the discourse of practical theology in the sense that it has provided a perspective on how the church can perform an effective transformational task that consists of a good understanding of the target community and principles of community transformation that are built on biblical norms. It has also provided guidelines on how to engage the community in a responsible and organised process that will empower people to become self-reliant and to benefit from their Godgiven resources. In this regard the study supports the view, referred to in the preceding article that the church has a significant role to play in transforming the whole person.

The specific guidelines developed through this MTh research study should, however, be practically implemented and critically monitored in the area where the research was conducted to endorse their relevance and practicality, because the aim of social research is to make valuable contributions to organisations and communities (Yarbrough et al. 2011). A subsequent doctoral (PhD) study focuses on the design, implementation and monitoring of a transformation strategy by the interdenominational church body in Sesheke.

\section{Acknowledgements}

To God my Creator in whom I live, move, and have my being, be all glory and honour forever. 
I also acknowledge the following people without whom this work would not have been possible:

- My wife Agness and children Lydia, David and Favour for supporting and encouraging me in my studies.

- My study leaders, Prof. W.J. Hattingh, Dr R. HattinghRust, and co-study leader, Prof. Ferdi Kruger for the super skills they displayed in guiding, supporting, and motivating me.

- Dr P.J. Oldewage who acted as the independent coder for my interview transcriptions.

- Maria Moroalle and Martie Serfontein for coordinating my study program from Auckland Park Theological Seminary (ATS) principal's office.

- Dr L.J. Erasmus for providing me with the important books that I needed for my study and also for the spiritual and moral support he gave me.

- The members of the Pastors Fellowship and community leaders (senior citizens) of Sesheke for providing me with vital information regarding the Sesheke Church's transformational task.

\section{Competing interests}

The authors declare that they have no financial or personal relationships which may have inappropriately influenced them in writing this article.

\section{Authors' contributions}

D.M. is the researcher and corresponding author of this article. R.H-R. and W.J.H. were study supervisors and coauthors of the article.

\section{References}

Abiche, T.T., 2004, 'Community development initiatives and poverty reduction', Unpublished dissertation - Masters, University of Western Cape.

Adejunmobi, A., 1990, 'Self-help community development in selected Nigerian rura communities: Problems and prospects', Community Development Journal 25(3) 225-235. https://doi.org/10.1093/cdj/25.3.225

Adeyemo, T. (gen. ed.), 2006, Africa Bible commentary, WordAlive Publishers, Nairobi.

Akrong, A., 1999, 'African traditional religion and development: Clash of two worlds of discourse and values', Paper presented at the TICCS Culture and Development Seminar, 01-02 November, Tamale.

Allen, S.D. (ed.), 2004, Truth and community transformation: Foundational principles for distinctively community development, International Bible Society, Arizona, AZ.

Attanasi, K. \& Yong, A., 2012, Pentecostalism and prosperity: The socio-economics of the charismatic movement, Palgrave Macmillan, New York.

Awolalu, J.O., 1996, 'What is African traditional religion?', Studies in Comparative Religion 10(2), 1, viewed19February2016, from www.studiesincomparativereligion. com

Berkley Centre for Religion, Peace, and World Affairs, 2015, A discussion with Peter Berger: Professor emeritus at Boston University, viewed 20 October 2016 from $\mathrm{https}$ ://berkleycenter.georgetown.edu/interviews/a-discussion-with-peterfrom https://berkleycenter.georgetown.edu/interviews/a-discussion-with-peterberger-pro
da22e99c

Blackman, R., 2007, Partnering with the local church, Tearfund, Teddington.

Burns, N. \& Groove, S., 2009, The practice of nursing research: Appraisal, synthesis, and generation of evidence, Saunders Elsevier, St Louis Missouri.

Cernea, M.M. (ed.), 1991, Putting people first: Sociological variables in rura development, Oxford University Press, New York.

Chambers, R., 1983, Rural development: Putting the last first, Longman, Essex.

Collier, P., 2007, The bottom billion: Why the poorest countries are failing and what can be done about it, Oxford University Press, Oxford.

Dahama, O.P. \& Bhatnagar, O.P., 1985, Education and communication for development 2nd edn., Oxford \& IBH Publishing, New Delhi.
De Wet, H.L., 2011, Understanding transformational development in World Vision South Africa: Conceptualisation and operationalization, International Institute of Social Studies, The Hague.

Dodge, C.P. \& Bennette, G., 2011, Changing minds: A guide to facilitated participatory planning, Fountain Publishers, Kampala.

Dreyer, J.S., 2008, Practical theology and human well-being: An exploration of a multidimensional model of human action as conceptual framework, Practical Theology in South Africa 23(3), 3-22.

Foot, J. \& Hopkins, T., 2010, A glass half-full: How an asset approach can improve community health and well-being, IDeA, London.

Gabriel, T., 1991, The human factor in rural development, Belhaven Press, London.

Goldthorpe, J.E., 1990, The sociology of the third world: Disparity and development, 2nd edn., Cambridge University Press, Cambridge.

Goodall, C., 2012, Sustainability: All that matters, Hodder \& Stoughton, London.

Jeppe, W.J.O., 1985, Community development: An African rural approach, Africa Institute, Pretoria.

Khan, M.H., 2006, Governance and anti-corruption reforms in developing countries: Policies, evidence and way forward, G-24 discussion paper series: Research Policies, evidence and way forward, G-24 discussion paper series: Research
papers for the Intergovernmental Group of Twenty-Four on International papers for the Intergovernmental Group of Twenty-Four on International Monetary Affairs and Development, 42, United Nations Conference on Trade and Development, New York, viewed 14 February 2016, from http://unctad.org/en/
docs/gdsmdpbg2420064 en.pdf

Korter, J., 1991, 'Leading change: Why transformation efforts fail', in A. Igantius (ed.) Harvard business review on change, pp. 59-60, Harvard Business School Press, Boston, MA

Kraufmann, D. \& Kraay, A, 2003, 'Growth without governance', Economia: The Journal of the Latin American and Caribbean Economic Association 3(1), 169-215.

Kretzmann, J. \& McKnight, J., 1993, Building communities from the inside out, ACTA Publications, Chicago, IL.

Lopez-Ridaura, S., Van Kuelen, H., Van Ittersum, M.K. \& Leffelaar, P.A., 2005, 'Multiscale sustainability evaluation: Quantifying indicators for different scales of analysis and their trade-offs using linear programming', International Journal of Sustainable Development and World Ecology 12, 81-97, in R. Ruben, J. Pender, \& A. Kuyvenhoven, 2007, Sustainable poverty reduction in less-favoured areas, CABI, Oxfordshire.

Lord, J. \& Hotchison, P., 1993, 'The process of empowerment: Implications for theory and practice', Canadian Journal of Mental Health 12(1), 5-22. https://doi. org/10.7870/cjcmh-1993-0001

Mathewes, C.T., s.a., An interview with Peter Berger, viewed 20 October 2016, from http://www.iasc-culture.org/THR/archives/AfterSecularization/8.12PBerger.pdf

Maser, C., 1997, Sustainable community development: Principles and concepts, St. Lucie Press, Delray Beach.

Matunhu, J., 2011, 'A critique of modernisation and dependence theories in Africa: Critical assessment', African Journal of History and Culture 3(5), 65-72.

Milojevic, B., 2012, Influential factors on the urban transformation of cities in Bosnia and Herzegovina in the period of transition, viewed 20 February 2016, from http://www.isocarp.net/Data/case_studies/2146.pdf

Mohaneng, T., 2000, 'Community development and empowerment', in F.C. de Beer \& H.J. Swanepoel (eds.), Introduction to development studies, pp. 125-129, Oxford University Press, Cape Town.

Myers, B.L., 1999, Walking with the poor: Principles and practices of transformationa development, Orbis Books, Maryknoll, NY.

Osmer, R.R., 2008, Practical theology: An introduction, Eerdmans, Grand Rapids, MI.

Page-Adams, D. \& Sherraden, M., 1997, 'Asset-building as a community revitalization strategy', Social Work 42(5), 423-434. https://doi.org/10.1093/sw/42.5.423

Quinn, R., 1996, Deep change: Discovering the leader within, Jossey-Bass, San Francisco, CA

Sachs, J.D., 2015, The end of poverty: Economic possibilities for our time, Penguin Books, New York.

Simpson, D. (ed.), 2002, Capacity building for sustainable development: An overview UNEP environmental capacity development initiatives, viewed 13 July 2016, from http://unep.org

Swanepoel, H. \& De Beer, F., 2015, Community development: Breaking the cycle of poverty, 5 th edn., Juta, Lansdowne.

TerHaar, G. \& Ellis, S., 2006, 'The role of religion in development: Towards a new relationship between the European Union and Africa', The European Journal of Development Research 18(3), 351-367. https://doi.org/10.1080/09578810600 893403

Tesoriero, F., 2010, Community development: Community-based alternatives in an age of globalisation, Pearson, Frenchs Forest.

United Nations Economic Commission for Africa, 2013, Economic transformation for Africa's development: C -10 meeting, United Nations, Washington, DC.

Van Hoek, E. \& Yardley, S., 2009, Keeping communities clean: The church's response to improving sanitation and hygiene, Tearfund, Teddington.

Vinya, R., Syampungani, S., Kashole, D. \& Wamunyima, S., 2012, Forest sector in Zambia: Reviewing progress and addressing challenges and opportunities, Mission Press, Ndola.

Wallerstein, N., 1992, 'Powerlessness, empowerment and health: Implications for health promotion programs', American Journal of Health Promotion 6(3),197-205. https://doi.org/10.4278/0890-1171-6.3.197 
Walvis Bay Corridor Group, 2016, Trans Caprivi Corridor, viewed 03 October 2016 from http://www.wbcg.com.na/corridors/trans-caprivi-corridor.html

Whitmore, E., 1988, 'Empowerment and the process of inquiry', A paper presented at the Annual Meeting of the Canadian Association of Schools of Social Work, s.a., Windsor, ON

Woodbridge, N., 2014, 'The EDNA model for doing research in practical theology: A biblical approach', Conspectus 17, 89 .
Woodhead, L., Kawanami, H. \& Patridge, P. (eds.), 2009, Religions in the modern world: Traditions and transformations, 2nd edn., Routledge Taylor \& Francis, New York.

Yabrough, D.B., Shuhla, L.M., Hopson, R.K. \& Caruthers, F.A., 2011, The program evaluation standards: A guide for evaluators and evaluation users, 3rd edn., Sage, Thousand Oaks, CA.

Zuern, E., 2011, The politics of necessity: Community organising and democracy in South Africa, The University of Wisconsin Press, Madison, WI. 